\title{
A EDUCAÇÃo Na INTERNACIONAL COMUnista
}

\begin{abstract}
Cássio Diniz
Pós-doutorando pela Universidade Nove de Julho. Doutor em Educação pela Uninove. Professor do curso de História da Universidade do Estado de Minas Gerais, unidade de Campanha - MG - Brasil. ORCID: https://orcid.org/0000-0001-7551-4688 cassiodiniz@hotmail.com

Carlos Bauer Doutor em História pela FFLCH-USP. Professor do Programa de Pós-Graduação em Educaçáo da Universidade Nove de Julho. São Paulo, SP - Brasil ORCID: https://orcid.org/0000-0003-1031-5631 carlosbauer1960@yahoo.com.br

Isabella Delcorso Mestre e Doutoranda em Educaçấo pela Universidade Nove de Julho. São Paulo, SP - Brasil ORCID: https://orcid.org/0000-0003-3734-2680 isabelladelcorso@gmail.com
\end{abstract}

Resumo: Esse manuscrito tem como proposta analisar as perspectivas educacionais que se processaram e se desenvolveram no seio da Terceira Internacional, também conhecida como A Internacional Comunista (IC). A metodologia de pesquisa sustenta-se em fontes bibliográficas, na descrição crítica de sua trajetória histórica e na ênfase que essa organização da classe trabalhadora deu ao estabelecimento da pedagogia socialista e na sua disseminação como parte dos seus propósitos de intervenção política de alcance mundial. A sua principal finalidade é reconhecer a importância da IC para o movimento internacional dos trabalhadores, recuperar sucintamente alguns aspectos de sua história e procurar localizar os autores, as preocupaçóes teóricas e os desafios que se colocaram para aqueles que atuaram em suas fileiras e tinham como prioridade a intervenção no campo educacional, como foi o caso destacado de Nadezhda Krupskaya. As gravuras e fotografias utilizadas ao longo do artigo têm caráter ilustrativo, são de domínio público e constituem o acervo dos autores.

Palavras-chave: História da Educação. Internacional Comunista. Pedagogia Socialista.

Aвstract: The purpose of this manuscript is to study the educational perspectives that were processed and developed in the Third International, also know as The Communist International (CI). The reserarch methodology is based on bibliographic sources, in the 
critical description of his historical trajectory, and in the emphasis of this working class organization has places on the establishment of socialist pedagogy and its dissemination as part of its purpose of world political intervention. In primary, your main purpose is to recognize the importance of CI for the internacional labor movement, succinctly retrieve some aspects of your history and research in the authors the theoretical concerns and challenges they pose to those who work in their field and had priority in educational intervention as the case of Nadezhda Krupskaya. The prints and photograps used in the article are for illustrative purposes, in the public domain and constitute the collection of the authors.

KeYwords: Education History. Communist Internacional. Socialist Pedagogy.

\section{Introdução}

O ano de 2019 é marcado na história da classe trabalhadora mundial pela lembrança dos cem anos da fundaçấo da Internacional Comunista (IC), ocorrida entre os dias de 2 e 6 de março de 1919, no bojo das atividades do I Congresso Mundial da Internacional Comunista, realizado em Moscou. Tal fundação se deu em meio às ruínas e a destruição humana causada pela Primeira Guerra Mundial, os vestígios da Guerra Civil na Rússia, com o regime bolchevique sendo virulentamente reprimido por açóes militares e o bloqueio econômico estadunidense e das potências europeias, causas nevrálgicas e decisivas para o número demasiadamente pequeno de participantes em suas atividades inaugurais, que contaram com 51 delegados, representando 34 partidos.

O presente manuscrito tem como o seu principal objetivo reconhecer a importância da IC para o movimento internacional dos trabalhadores, recuperar criticamente alguns aspectos de sua história e procurar localizar as preocupaçóes teóricas e os desafios que se colocaram para aqueles que atuaram em suas fileiras e tinham como prioridade a intervenção no campo educacional.

Nos fins da década de 1910, a Revolução Russa galvanizava a atenção e mobilizava a ação dos movimentos revolucionários socialistas do mundo inteiro, e a Internacional Comunista haveria de cumprir um papel determinante em sua articulação, como também, poucos anos depois, na constituiçáo das Brigadas Internacionais que lutaram ao lado dos republicanos na heroica tentativa de barrar o avanço do fascismo espanhol (1936-1938). 
Objetivamente, a IC ofereceu todo o tipo de apoio à juventude e aos lutadores da classe trabalhadora que sofriam perseguiçóes políticas em seus países. Desenvolveram e intensificaram a valorização de açôes educacionais associadas ao trabalho de formação política e editorial, com a efetivação de escolas de quadros sobre a teoria revolucionária e os fundamentos do marxismo, além de se constituírem em ponto de apoio para os partidos revolucionários e na disseminação das informaçóes políticas de interesse da classe trabalhadora em todo o mundo.

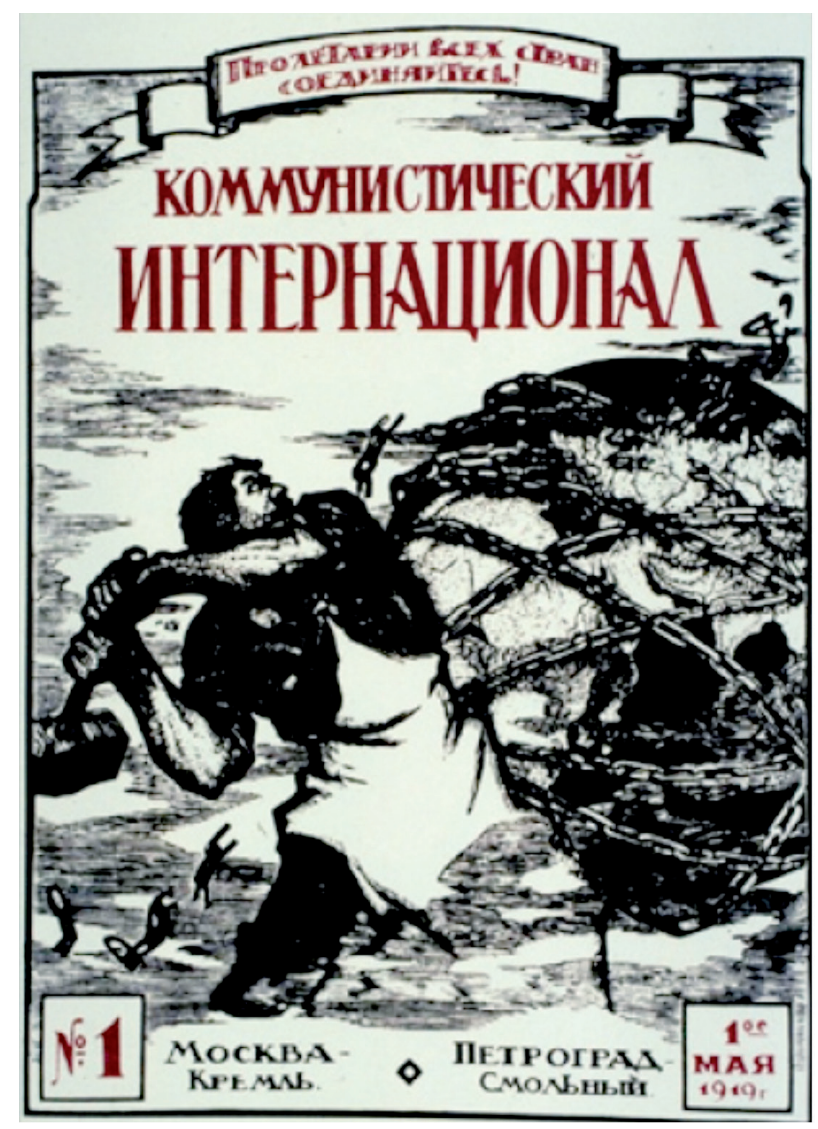

Edição número 1 da revista d'A Internacional

Fonte: Acervo do Centro de Documentação e Memória (CEDEM), da Universidade Estadual Paulista (UNESP) 
A herança política e revolucionária da Internacional Comunista não pode ser desprezada, muito menos esquecida, ainda mais em um momento da história em que a luta de classes cobra um alto preço dos trabalhadores, e exige dos seus dirigentes e de sua vanguarda política a formulação de uma estratégia revolucionária capaz de derrotar e superar o poderio do capitalismo.

\section{Apontamentos sobre a história das internacionais}

Desde a sua publicação em 21 de fevereiro de 1848, com o título original de Manifesto do Partido Comunista, Karl Marx e Friedrich Engels deram forma ao caráter internacionalista e sem quartel da luta da classe trabalhadora. Nessa obra da luta comunista internacional, estão colocadas como fatores decisivos a derrocada do capitalismo e a organização da classe trabalhadora em escala mundial como possibilidades históricas de superação da disputa pelo controle dos mercados, das riquezas naturais, das matérias-primas e da riqueza socialmente produzida.

Foram Marx e Engels que reconheceram o papel histórico da classe trabalhadora e apontaram a necessidade de criação da Associaçáo Internacional dos Trabalhadores, mais tarde conhecida como a Primeira Internacional. Fundada em 28 de setembro de 1864, por representantes de sindicatos de trabalhadores do setor comercial, industrial, por sociedades mutualistas, agrupamentos de intervenção no setor cultural, organizaçóes políticas e de caráter conspiratório contra o capital.

A Primeira Internacional se constituiu por intermédio de seções organizadas em inúmeros países, embasados no princípio da solidariedade internacional dos trabalhadores, e contribuiria para o fortalecimento da organização política da classe operária e de suas açóes.

A Associação Internacional dos Trabalhadores foi dissolvida em 1876, diante de sua incapacidade de superar as adversidades que trouxeram a derrota da Comuna de Paris em 1871, traduzindo de forma pungente as vicissitudes enfrentadas pela classe trabalhadora e o estágio imperialista que o capitalismo havia alcançado naquele instante da história mundial.

Posteriormente, a Segunda Internacional fincou seus alicerces em 14 de julho de 1889 na cidade de Paris, simbolicamente cem anos após a 


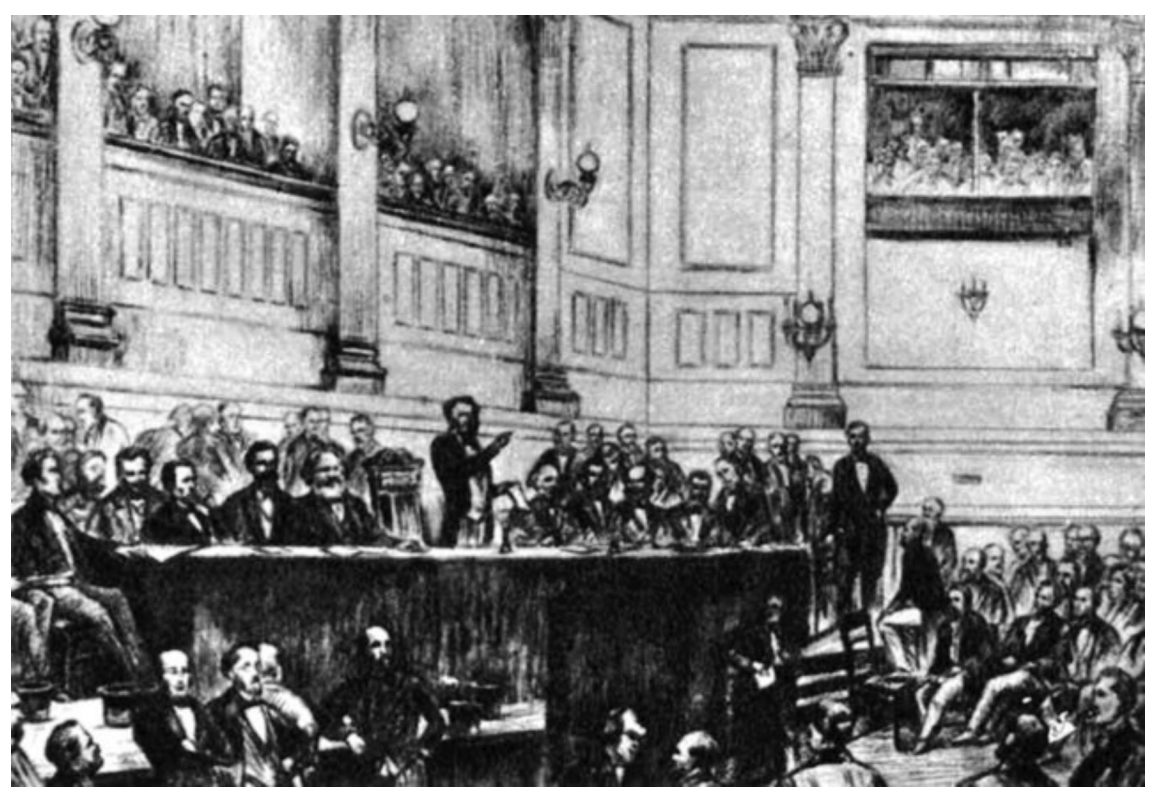

Gravura alusiva à fundação da Associaçáo Internacional dos Trabalhadores em Londres (AIT) em 1864 (Karl Marx, foi registrado sentado, à esquerda do orador)

Domínio público. Fonte: Acervo dos autores.

Queda da Bastilha e a eclosão da Revolução Francesa, num momento de acelerado desenvolvimento e mundialização do capital, com a constituição de monopólios e do capital financeiro. Sua estruturação se deu a partir dos partidos e associaçóes mais remotas da velha Internacional, criando condiçóes para que o avanço dos postulados e princípios marxistas tivesse um considerável desenvolvimento no movimento dos trabalhadores em escala mundial, embora seja importante reconhecer que a maioria dos partidos e organizaçóes sofresse hegemonia e a pressão dos restritos limites estruturais da legalidade burguesa, produzindo o que se convencionou chamar de reformismo.

$\mathrm{O}$ avanço do reformismo entre os partidos e organizaçóes que compunham a Segunda Internacional foi muito acentuado, pelo fato de que nos países ocidentais avançados e industrializados, por conta da exploração desmedida que operavam em suas investidas neocoloniais, possibilitou a 


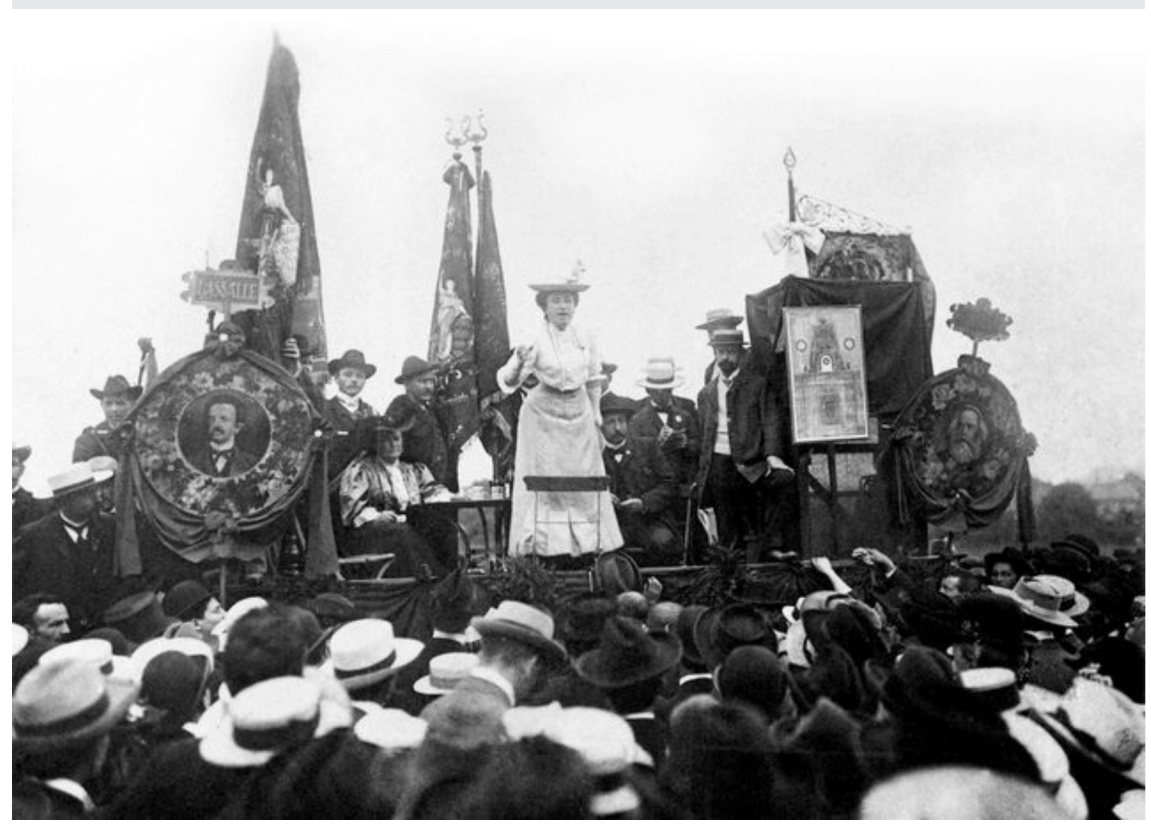

Rosa Rosa de Luxemburgo discursando, em 1907, em um comício no congresso da Segunda Internacional em Stuttgart, capital do estado de Baden-Württemberg, importante núcleo industrial no sudoeste da Alemanha

Domínio público. Fonte: Acervo dos autores.

outorga de concessóes aos trabalhadores e a constituição de uma numerosa aristocracia operária.

Por diferentes razôes, a Segunda Internacional não conseguiu se estabelecer como um ponto de apoio efetivo para o movimento revolucionário internacionalista, não cumprindo o seu papel de corporificar a unidade dos trabalhadores, nem estabelecer um programa, estatutos e veículos de comunicação que tornassem possível que as suas decisóes congressuais e do seu corpo diretivo fossem assimilados pelas seçôes nacionais.

Em 1916, a Segunda Internacional foi dissolvida em meio às pressôes nacionalistas que dilapidaram os interesses da classe trabalhadora e haviam mergulhado os povos nos horrores da Primeira Guerra Mundial, na manifestação dos interesses inescrupulosos da burguesia e do imperialismo contra a humanidade. 
Todos os partidos socialistas dos países beligerantes, salvo dois - o sérvio e o russo -, empunharam a bandeira da união nacional, alardeada pela classe dirigente: tornaram-se belicosos. Nos países neutros, os socialistas não foram muito melhores e o renegado Mussolini é o exemplo mais conhecido disso. Jean Jaures, o grande tribuno francês, cuja voz de trovão parecia ser a única capaz de fazer recuar a guerra, morreu pelas balas de um miserável, viciado no ópio patriótico. (BROUÉ, 2007, p. 15)

O ideário reformista reinante no seio da Segunda Internacional foi considerável - e a colaboração de classes também - e diante da guerra imperialista e das burguesias nacionais, houve exceçóes que jamais poderiam ser esquecidas, como foi caso dos bolcheviques russos liderados por Lênin e os representantes da Liga Spartacus da Alemanha de Rosa Luxemburgo, Frantz Mehring e Karl Liebknecht.

$\mathrm{Na}$ pena de Lênin temos uma importante contribuição à política e a organizaçáo revolucionária como instrumento de questionamento aos postulados ideológicos produzidos e reproduzidos pela educação burguesa. Sua concepção de educação partia dos valores marxianos, da defesa do seu amplo e irrestrito acesso aos trabalhadores - do campo e da cidade - e de que o projeto pedagógico socialista deveria estar assentado na politecnia e na permanente busca da formação humana integral.

Amiúde, Lênin trouxe uma série de contribuiçôes para articulistas como Nadezhda Krupskaya e Maria Ulinóvna que se dedicavam com tenacidade e afinco na construção de uma Pedagogia Socialista no calor da hora da revolução bolchevique.

\section{Aspectos históricos da Internacional Comunista}

As revoltantes consequências do extermínio humano da Primeira Guerra Mundial aceleraram as transformaçôes dos partidos socialdemocratas em organizaçóes contrarrevolucionárias e de caráter burguês. Por seu turno, a vitória e a consolidação política da Revolução Russa de 1917 estenderam sua influência revolucionária e internacionalista pelo mundo 
inteiro, contribuindo com a organização da classe trabalhadora de forma nunca antes vista.

Todos aqueles que, desde 1914, tomaram parte da luta contra a guerra e pelo renascimento do movimento operário internacional sentiram a vitória da revolução de outubro como um fato histórico. Clara Zetkin, fala de um 'evento exaltante', Rosa Luxemburgo, de um 'evento magnífico' e de 'elixir da vida'. Em sua crítica da Revolução Russa citada mais acima, ela escrevera também estas linhas ambíguas: 'Os "Lenins" e os "Trotskys" com seus amigos foram os primeiros que colocaram o proletariado mundial em primeiro lugar, como exemplo. Eles são os únicos até agora que podem escrever como Ulrich de Hütten: "Eu ousei”' (BROUÉ, 2007, p. 40-41)

A epopeia revolucionária russa colocou como tarefa imediata dos revolucionários do mundo inteiro a sua organização e unificaçáo no interior de uma única entidade, inspirada nos princípios marxistas e na defesa da Revolução de Outubro.

Num momento da história eivado de conflitos bélicos e sociais, 


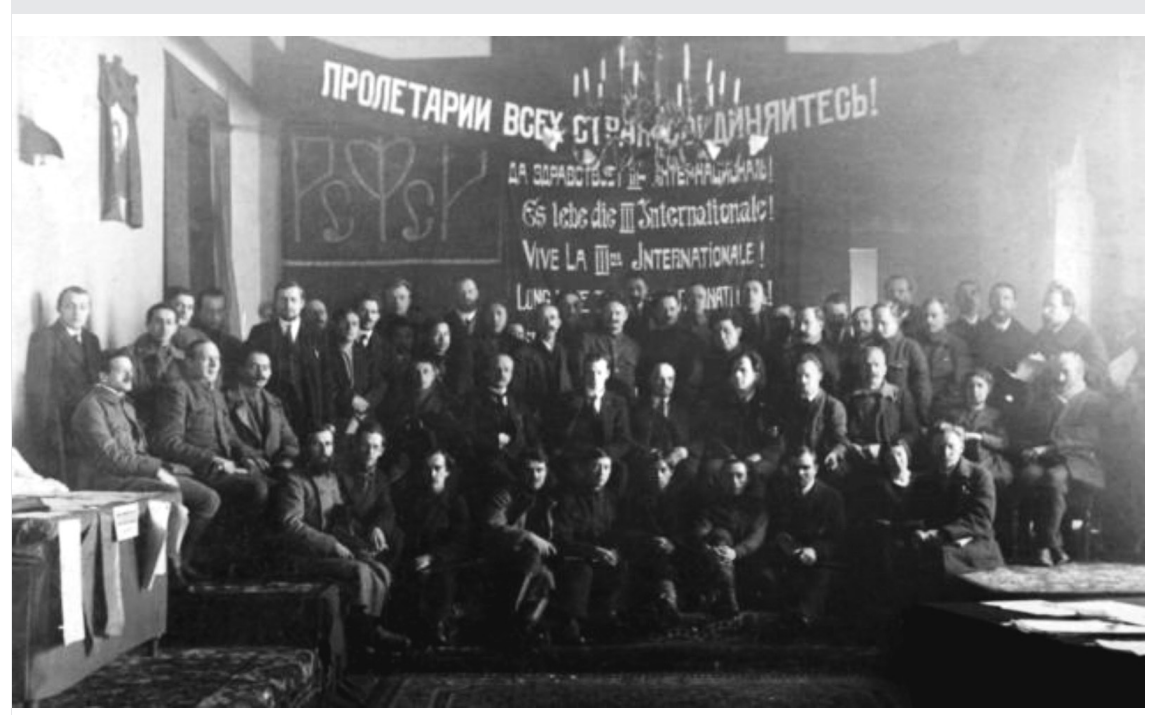

Participante do congresso de fundaçáo da Internacional Comunista em 1919

Domínio público. Fonte: Acervo dos autores.

Todos os autores insistiram no caráter pouco representativo dos delegados desse congresso de fundação. Trata-se de uma evidência. No total, 51 delegados tomaram parte nos trabalhos, levando em conta os que chegaram atrasados, os que saíram antes do final e as ausências momentâneas, dentre eles, oito delegados do PCR(b): Lenin, Trotsky, Zinoviev, Stalin, Bukharin, Tchitcherin e os dois suplentes, Obelensky-Ossinsky e Vorovsky. (BROUÉ, 2007, p. 94)

Esse importante episódio foi crucial para a realização, em novembro de 1919, na cidade de Berlim, do encontro que resultou na fundação da Internacional Comunista Jovem, com o objetivo de aglutinar as forças revolucionárias da juventude em torno de reivindicaçôes educacionais, vida digna, trabalho e a luta contra a militarização de suas vidas.

A Internacional Comunista nesses anos procurou se organizar para combater a presença crescente das correntes socialdemocratas no movimento dos trabalhadores, enfrentando a influência burguesa e as forças 
oportunistas que pressionavam pela adaptação ao discurso pacifista, que em sua propaganda preconizava o afastamento da classe trabalhadora da luta pelo poder e o seu acomodamento em alianças com os setores antibelicistas das burguesias nacionais que haviam capitulado ao imperialismo durante a Primeira Guerra Mundial, e procuravam recuperar sua hegemonia com concessóes aos trabalhadores em seus países.

A luta contra o fortalecimento e a consolidação da Revolução Russa era dirigida pela Labour Internacional, sediada em Amsterdã, apoiada pela Liga das Naçóes, que congregava os países imperialistas e se utilizava do seu Escritório Internacional do Trabalho com o intuito de estabelecer a acomodação da classe trabalhadora aos valores burgueses.

\section{A educaçáo no $2^{\circ}$ Congresso da Internacional Comunista}

O Segundo Congresso da Internacional Comunista foi realizado em Petrogrado e Moscou, no período de 6 a 25 de julho de 1920, votando seus estatutos e as teses de sua atuação preconizando a preparação imediata da luta pela ditadura do proletariado, a formação de partidos comunistas em todos os países e a combinação do trabalhão legal e clandestino.

O trabalho na esfera educacional é entendido como uma tarefa muito importante para ser desenvolvido pelos partidos afiliados à Internacional, começando pela preparação dos seus quadros com uma visão geral do marxismo que lhes possibilitasse uma visão crítica e transformadora da realidade social.

O quarto encontro congressual da Internacional Comunista se realizou entre os dias 30 de novembro a 05 de dezembro de 1924 em Moscou, tendo como pano de fundo as discussões sobre a situação dos comunistas no continente asiático, a situação dos negros na América e a necessidade dos comunistas não negligenciarem o trabalho dos comunistas nos sindicatos legalizados existentes no mundo capitalista.

Nesse congresso o trabalho educacional foi considerado como parte indissolúvel das atividades dos partidos comunistas integrante da Internacional, defendendo a disputa com as demais organizaçóes, associaçóes educacionais dos trabalhadores, universidades populares, 


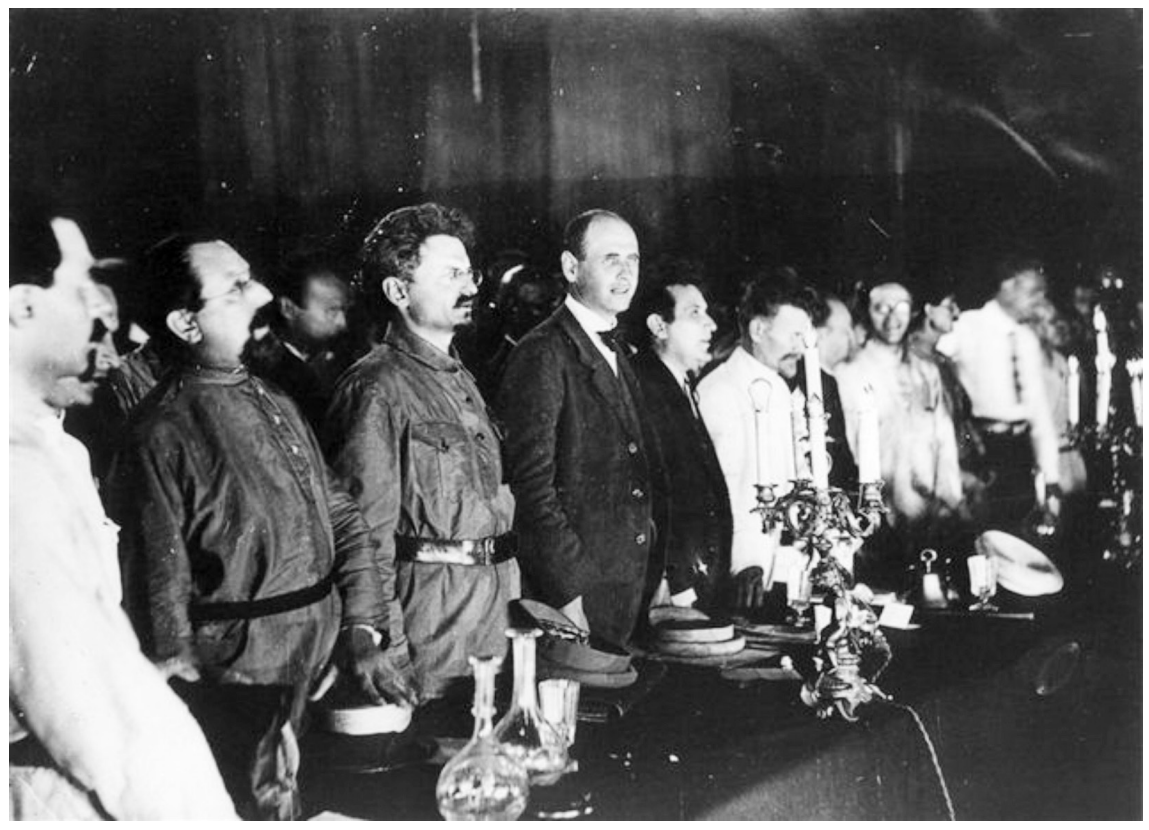

Segundo Congresso da Internacional Comunista (Trotsky é o terceiro da esquerda, ao lado de Paul Levi e Zinoviev), realizado em Moscou e Petrogrado, de 19 de julho a 6 de agosto de 1920. Domínio público Fonte: Acervo dos autores.

faculdades operárias e demais organizaçôes proletárias que atuassem na esfera educacional.

Para o desenvolvimento de suas atividades educacionais, os partidos comunistas deveriam ser estimulados a criar escolas nacionais e regionais, com aulas nos períodos matutinos, diurnos e noturnos, com professores especializados e palestrantes convidados para discutirem com as classes formadas, além de criarem bibliotecas e incentivarem a realização de atividades culturais. Os partidos membros da Internacional Comunista deveriam dar todo o apoio intelectual e material da juventude em seu trabalho organizativo e político no campo educacional.

As instruçóes sobre o trabalho educacional deveriam ser formuladas e disseminadas pela seção educacional, diretamente, ligada ao Comitê Executivo da Internacional Comunista. Essa seção foi pensada 
para ter sua atuaçáo estabelecida diretamente junto ao comitê executivo da Internacional, com a responsabilidade de compreender em profundidade as tarefas educacionais comunistas e orientar o trabalho das organizaçôes educacionais classistas.

A Internacional Comunista deveria se preocupar em registrar o acumulo das discussóes educacionais e se esmerar na efetivação do intercambio das múltiplas experiências internacionais, a disseminação dos métodos de estudos e de ensino existentes em diferentes países como, também, efetivar a compilação e edição de manuais, livros didáticos e livretos apropriados ao avanço dos problemas educacionais registrados nos países.

A seção de educação da Internacional deveria ainda assumir a responsabilidade pelas discussóes e produção de materiais pertinentes sobre os políticos dos partidos comunistas e da IC em relação as atividades escolares e a educação como um todo.

A consecução dessa tarefa da Internacional Comunista foi remetida à Academia Socialista na Rússia, que passou a organizar cursos básicos internacionais com o objetivo de desenvolver e fundamentar uma compreensão marxista da problemática educacional e de sua práxis.

\section{Consensos e polêmicas nos debates educacionais na União das Repúblicas Socialistas Soviéticas (URSS) e na Internacional Comunista}

O debate em torno de um projeto societário perpassa indiscutivelmente por modelos de educação e de cultura a serem refletidas e elaboradas, com o objetivo de não apenas preparar futuros quadros militantes com domínio da teoria e da prática revolucionária, mas também na formação integral do ser social, com a compreensão das problemáticas econômicas, políticas e culturais que favorecessem sua atuação na nova sociedade. Como parte de sua estratégia mundial, a Internacional Comunista assumiu a tarefa de elaboração e disseminação de novos ideais educacionais e pedagógicos, como parte da luta política pelo socialismo.

Contudo, seria negligente acreditarmos que os trabalhos realizados apenas nos congressos e nas instâncias deliberativas e executivas da Internacional garantiriam o escopo geral desse debate. Cabem-nos ressal- 
tar que todo o legado de uma querela anterior foi absorvido no interior desse organismo, como também as contribuiçôes ocorridas no âmbito interno da União das Repúblicas Socialistas Soviéticas (URSS) - como ficou mais conhecida, simplesmente, União Soviética - no mesmo período. Nesse caso, torna-se necessário analisar e compreender como se deu esse contributo por parte dos russos ao longo de seu processo revolucionário.

Como dito anteriormente, a educação tem determinada centralidade quando nos referimos ao projeto anticapitalista de transformação radical. No entanto, como leitores de Marx e Engels, precisamos entender o papel da educação dentro da lógica materialista dialética. Nesse caso, a educação é caminho ou consequência de uma luta pela tomada do poder pela classe trabalhadora?

É inegável que a formação teórica, técnica (consciente) e prática são fundamentais para a formação da base e da vanguarda do operariado em marcha. Somente com quadros militantes com o domínio da teoria revolucionária poderão colocar em prática os exercícios dialéticos da problematização, análise, caracterização e elaboração de estratégias e táticas no calor da luta de classes. Mas é importante destacar que a educação institucional por si só não se constitui como elemento de ação concreta pela destruição do modo de produção capitalista. Ao contrário, ela está em um espaço de intensa disputa ideológica no qual a classe trabalhadora enfrenta a hegemonia social e cultural da burguesia, instrumentalizada pelo aparato estatal que exerce o controle sobre os espaços escolares. A luta pela educaçáo pública torna-se então parte de um embate maior em torno do projeto societário do operariado.

Na luta pela escola pública é preciso ter como horizonte o direito de todos os que possuem um rosto humano à educaçáo de alta qualidade e, na sociedade burguesa, como dever do Estado. Mas, ainda assim, o Estado não pode ser, ele mesmo, o educador, pois o Estado é particularista, burguês e, por isso, como salientou Marx 'é o Estado que necessita de uma muito rude educação pelo povo’. (LEHER, 2017, p. 59)

Na mesma linha, Aníbal Ponce (2000) aponta que a educação é um processo mediante o qual as classes dominantes, em um determinado perí- 
odo histórico, estabelecem os meios ideológicos e culturais de sua dominação sobre todas as demais, no contexto da luta de classes. Como o exército, a polícia e a burocracia estatal, a escola cumpre um papel de dominação e subjugação de toda a sociedade. E isso se expressa não apenas nos planos educacionais, mas também nas concepçôes pedagógicas produzidas e praticadas no ambiente escolar.

Os ideais pedagógicos não são criaçôes artificiais que um pensador elabora em isolamento e que, depois, procura tornar realidade, por acreditar que elas são justas. Formulações necessárias de classes que estão empenhadas na luta, esses ideais não são capazes de transformar a sociedade, a não ser depois que a classe que os inspirou tenha triunfado e subjugado as classes rivais. (PONCE, 2000, p. 169)

No contexto da Rússia no início do século XX, esse mesmo debate educacional se fez presente. Nesse caso náo fazemos uma dicotomia entre a educação antes e depois de 1917, mas sim inserido enquanto um processo revolucionário longo, nos quais diferentes posturas políticas ocorrem até a transição definitiva ao comunismo. Nesse mesmo tempo, de acordo com Vladimir Lênin, é tarefa do novo Estado Operário o papel de transformar a então escola pública sob o controle da burguesia em uma escola de destruição desse controle burguês, a serviço da formação do novo homem, livre da cultura e dos vícios da antiga classe dominante.

Cabe destacar a intensa preocupação do líder da Revolução de Outubro em torno da educação na Rússia. A partir das pesquisas realizadas por Marisa Bitar e Amarílio Ferreira Jr. podemos ter acesso a diversos textos públicos que expóem essa preocupação. De acordo com esses historiadores, Lênin colocava o ensino das massas como prioridade fundamental do processo revolucionário, sendo que as palavras do revolucionário "traziam a marca da urgência histórica em defesa das transformaçôes estruturais necessárias para a construção da sociedade socialista no contexto de uma conjuntura internacional adversa." (BITTAR; FERREIRA Jr., 2011, p. 379)

$\mathrm{Na}$ ocasião do Terceiro Congresso Pan-Russo da União dos Jovens, Lênin expôs que a educação das massas está diretamente ligada à luta das 
mesmas contra o regime de opressão, mesmo no interior da velha escola. "A milenária separação entre as forças mentais e as forças físicas, que surgiu na história no mesmo instante em que a comunidade primitiva se converteu em sociedade de classes, desaparece, assim, sob o impulso do proletariado." (LÊNIN, apud PONCE, 2000, p. 173)

A tomada do poder em outubro de 1917 trouxe à tona uma realidade que o novo governo deveria se ater: o baixo nível escolar da população russa, cuja maioria ainda estava mergulhada em um extremo analfabetismo, além da carência absurda de técnicos e profissionais comprometidos com a causa revolucionária. A tarefa do novo Comissariado do Povo para a Educação ${ }^{1}$, na figura de seu comissário Anatoli Lunacharsky, era possibilitar os meios políticos, ideológicos e financeiros para a superação desses problemas imediatos.

O empenho de Vladimir Lênin e dos bolcheviques preocupados com essa problemática não terminaram por aí. Os intensos debates ocorridos no interior do VIII Congresso do Partido Comunista - realizado em março de 1919 - culminaram na aprovação de uma importante resolução, que definiu:

1- Instrução geral e politécnica gratuita e obrigatória para todas as crianças e adolescentes dos dois sexos, até os 17 anos de idade; 3- Plena realização dos princípios da escola única do trabalho, com o ensino na língua materna, estudo em comum das crianças dos dois sexos, absolutamente laica, livre de qualquer influência religiosa, que concretize uma estrita ligação do ensino com o trabalho socialmente produtivo, que prepare membros plenamente desenvolvidos para a sociedade comunista. (MANACORDA, 2001, p. 314-315)

Como primeira tarefa, a luta contra o analfabetismo se materializou na Likbez, um decreto governamental de 1919 visando a alfabetização em massa da população entre os oito e 50 anos de idade. No ano seguinte foi criada a Comissão Extraordinária para a Eliminação do Analfabetismo, com o objetivo de coordenar os esforços em prol da alfabetização da Rússia. Parte importante da juventude e da intelectualidade proletária se uniu 
nesse esforço nacional, cujo lema era "Que aquele que sabe ler e escrever ensine àquele que náo sabe".

Porém, os desafios eram grandes. Além dos problemas elencados acima, devemos considerar que parte do movimento revolucionário não tinha pleno acordo em torno do papel do Estado na educaçáo e na cultura soviética. A questão era se essas tarefas deveriam ficar sob a responsabilidade direta do Estado - por meio de seus comissariados da educação e do trabalho e demais órgãos - ou a cabo de coletivos semiindependentes de educadores, artistas e da juventude operária, dentro do espírito revolucionário dos sovietes, como o movimento Proletkult ${ }^{2}$, que de acordo com os princípios já descritos acima abominavam a participação estatal na condução da educação e da cultura. Poderemos observar ao longo dos anos da próxima década um duro embate no qual o Estado Soviético conseguiu suplantar e controlar as demais iniciativas particulares da classe trabalhadora russa, estabelecendo os fundamentos nevrálgicos de uma educação socialista.

Dentro desses marcos, construiu-se o consenso da necessidade de superar o modelo educacional burguês pautado pela divisão do trabalho (e do conhecimento) manual e intelectual. Cabia ao novo poder, estabelecer os parâmetros que definiram a educação como integral e politécnica, no qual o ensino teórico está profundamente ligado ao ensino prático voltado pelo domínio do mundo do trabalho nas suas mais diferentes vertentes.

Seguindo essa análise, na sociedade em transição ao comunismo, a escola se torna o centro irradiador do conhecimento socialmente produzido no interior de uma comunidade. $\mathrm{Na}$ nova concepção coletivista da sociedade (sociedade sovietizada), a educação ganha novo papel na formação e na preparação da juventude para uma nova atuação consciente, baseada na participação ativa na vida social, econômica e política em uma realidade sem classes social, bem diferente da escola de um período histórico anterior, assentada nas estruturas sociais com divisôes antagônicas e a sobreposição de uma classe sobre a outra.

No projeto histórico da classe trabalhadora, o operariado e o campesinato assumem o controle dos meios de produção por meio de seu Estado. Com esse novo atributo, a educação ganha finalidades no contexto geral desse projeto. É por isso que necessariamente ela precisa ser radicalmente distinta da educaçáo burguesa; abandonar a escola livresca e se dedicar à 
construção de uma escola prática, cujo conhecimento esteja lastreado pela realidade concreta e de interesse direto da sociedade.

Porém, outro embate se deu nesse espaço: caberia à nova educação socialista construir seu conhecimento a partir de novos paradigmas, fugindo dos vícios burgueses, ou essa educação se construiria a partir das ruínas do antigo modelo, se aproveitando do legado do conhecimento historicamente construído e acumulado pela humanidade, mesmo que sob a hegemonia da então classe dominante? Como paralelo e exemplo, polêmica parecida ocorreu de forma mais dramática durante a Guerra Civil, quando Trotsky e Lênin estiveram diante da polêmica em aceitar a inserção de 30 mil oficiais das antigas Forças Armadas czaristas no novo Exército Vermelho.

Para Lênin e, depois, para Lunacharsky, era preciso se aproveitar do legado educacional anterior, fazer a sua crítica e socializá-la para classe trabalhadora, adaptando-a a nova realidade revolucionária. "Por isso, ao rejeitar a velha escola, propusemo-nos a tarefa de tomar dela apenas aquilo que nos é necessário para conseguir uma verdadeira formação comunista." (LÊNIN, apud BITTAR; FERREIRA Jr., 2011, p. 383)

Nesse debate, não podemos deixar de levar em consideração as novas tendências e experiências pedagógicas que se operavam em outros países e até mesmo de fora da esfera revolucionária. Um caso específico é citado por Bittar e Ferreira Jr., ao trazer a luz o interesse de Lênin na chamada Educação Nova e nas contribuiçóes de John Dewey. De acordo com Manacorda (2001, p. 313), Lênin teria dito à sua companheira Krupskaya: "É preciso estudar minuciosamente a experiência americana, é preciso fazer nosso tudo aquilo que se conseguiu nos países capitalistas, avaliá-lo com base no critério da nossa posição marxista e ver o que nos convém e o que não nos convém", demonstrando a sua visão de que era necessário absolver as melhores contribuiçóes possíveis existentes no campo educacional, a exemplo de suas reflexôes acerca do taylorismo no campo da produção industrial.

Não obstante, opinião diferente tinha o Proletkult, que fazia duras críticas à herança burguesa na cultura, nas artes e na educação.

O grande risco da apropriação do acervo de conhecimento produzido na sociedade burguesa é a reprodução do que podería- 
mos denominar de 'ideologias dominantes': a crítica ao conhecimento produzido na sociedade burguesa não necessariamente rompe com os marcos da cultura burguesa, reproduzindo a forma de ver, sentir e viver burgueses. (LEHER, 2017, p. 70)

Nadezhda Krupskaya, uma das vozes mais importantes no interior do Comissariado do Povo para a Educação, tinha posiçôes ambivalentes em relação às ciências, sobretudo sociais. Para ela, a objetividade científica era permeada pelo ethos dominante. As contribuiçôes científicas realizadas pela burguesia seriam carregadas desses vícios burgueses, apesar delas não poderem ser simplesmente ignoradas na etapa revolucionária na qual se encontravam. Lunacharsky se aproximou dessa última análise, apontando a necessidade do proletariado em construir seu conhecimento fazendo uso do legado científico do passado.

Dentro dessa lógica pedagógica, é importante observarmos as demais contribuiçóes de Krupskaya, com destaque aos trabalhos em torno da matriz curricular. Em uma proposta de modelo de plano de estudos elaborada por meio da Seção Pedagógica do Conselho Científico Estatal, Nadezhda apresenta a ideia de uma matriz baseada em um tripé curricu- 
(MANACORDA, 2001, p. 316), trouxe importantes reflexôes sobre o conhecimento e a sua construção social.

Conforme alguns dos seus intérpretes haviam notado, para Anton Makarenko (apud FILONOV, 2010, p. 15),

[...] a força da educação, na sociedade socialista, está na utilização judiciosa, pelos pedagogos, dos dados, da psicologia, da biologia, da medicina, em suma, de todas as ciências do homem, chamadas a desempenhar um papel na organização prática do processo educativo e na pesquisa pedagógica.

Para além dessas polêmicas, a realidade prática impunha desafios concretos. A carência de uma força de trabalho especializada ameaçava paralisar a nova economia soviética. Criou-se a necessidade urgente de uma formação rápida que suprisse as demandas da produção industrial e agrícola. Novas escolas politécnicas tinham que ser erguidas e postas a funcionar, mesmo no difícil contexto da Guerra Civil.

$\mathrm{O}$ risco do barateamento do ensino e da formação técnica não era bem visto por parte da intelligentsia, também preocupada com a produtividade das fábricas e do campo. A isso se somou parte do diminuto professorado, ainda preso às velhas tradiçôes e pouco afeto ao novo poder soviético. O resultado foram os atos de resistência que seriam apenas superados depois de 1926.

Todo o acúmulo desse debate foi aproveitado também no âmbito das instâncias da Internacional Comunista. Tendo como responsabilidade a divulgação dos ideários educacionais de cunho operário para o mundo, cabia a ela definir as linhas mestras e as políticas de formação durante os processos revolucionários a ocorrerem pelo mundo, adaptados a cada realidade existente na Europa, nas Américas, na Ásia e na África.

Para Lênin, o processo educacional também tinha um papel fundamental na formação desses quadros militantes, inclusive a nível internacional. Para o revolucionário, de nada adianta alguém se declarar comunista se não conhecer os preceitos e princípios básicos da teoria revolucionária.

No entanto, enganar-se-ia quem, apressadamente, acreditasse que essa fosse uma tarefa simples. Lênin é categórico ao desfazer 
essa ilusão, afirmando que ninguém se tornaria um verdadeiro comunista nutrindo-se apenas de palavras de ordem, o que, aliás, seria perigoso. Por isso, assinala: "Deveis educar-vos para serdes comunista". Ele insiste em que a formaçáo intelectual demandaria esforço próprio para compreender os desafios da nova situação, combinando teoria e capacidade de intervenção prática. Os princípios, segundo ele, se fossem desvinculados da compreensão sobre a situação em que se encontrava a Rússia naquele momento, de nada serviriam "porque prolongariam o antigo divórcio entre a teoria e a prática", o "mais repugnante traço da velha sociedade". (BITTAR e FERREIRA Jr., 2011, p. 382)

Ao longo das décadas seguintes, o debate educacional no interior do movimento comunista internacional sofreu as contribuiçóes de outros teóricos, que de uma forma ou de outra nos possibilitaram avançar tanto com as reflexôes quanto com propostas, concepçóes e projetos de escola da nova sociedade socialista. Ganhou destaque os trabalhos de Antonio Gramsci, que a partir de sua monumental obra - entre eles os Cadernos do Cárcere $^{3}$ e o livro Os Intelectuais e a Organização da Cultura ${ }^{4}$, entre outros -, trabalharam o conceito de cultura e educação e o papel da luta política da classe trabalhadora e de sua vanguarda nesses espaços de disputa ideológica no interior da sociedade burguesa.

Com seus trabalhos, Gramsci pode inspirar outras reflexóes ao longo dos anos, atravessando mesmo os limites temporais da Internacional Comunista e chegando aos dias atuais. Cabe destacar também a sua busca por uma definição de um papel mais claro, enquanto essência e cultura, para a educação durante o processo de transição, que tem como objetivo buscar substituir o modelo de ser greco-romano por um ser socialista e coletivista.

[...] Gramsci relaciona sempre o fato educativo não somente ao fato político, mas também e especialmente ao fato da produção e do trabalho, ou, como ele diz, do industrialismo concebido como a contínua vitória do homem sobre a natureza externa e sobre seus instintos. (MANACORDA, 2001, p. 334) 
Com seus trabalhos, Gramsci pode inspirar outras reflexôes ao longo dos anos, atravessando mesmo os limites temporais da Internacional Comunista e chegando aos dias atuais, se transformado também em referência teórica para outros agrupamentos de esquerda que não compartilhavam do espectro stalinista.

\section{A construçáo da Pedagogia socialista: o legado de Krupskaya}

Nadezhda Konstantinovna Krupskaya nasceu em 1869, em São Petersburgo, e faleceu em 1939, em Moscou. Filha de oficial das Forças Armadas do Império Russo, teve de parar seus estudos aos 14 anos, após a morte do pai. Apenas em 1889 entraria para uma escola superior feminina para estudar pedagogia. Entre 1891 e 1896 passou a lecionar em uma escola dominical frequentada por trabalhadores, época em que se aproximou do marxismo e começou a participar de círculos de discussão clandestinos sobre o tema.

Em 1894 Krupskaya conheceu Lênin e, um ano depois, fundaram a organização socialdemocrata União de Luta pela Emancipação da Classe Operária. No mesmo ano Lênin foi preso, e pouco tempo depois, durante as greves de 1896, Krupskaya também foi detida, sendo condenada a três meses de cadeia e três anos de deportação na Sibéria, onde encontrou Lênin e se casaram em 1898. Em 1901, Lênin e Nadezhda mudaramse para Munique e, depois, para Londres. Apenas em 1905 retornaram à Rússia. Contudo, em 1908, o casal conheceu um novo exílio.

Além de contrair matrimônio com Lênin, Krupskaya tornou-se uma de suas principais colaboradoras, especialmente no que cerne à educação, pensando nos problemas pedagógicos do estado proletário em que viviam, refletindo sobre a formulação de um projeto de ensino realmente formador e participativo. Ao longo de sua vida, Nadezhda construiu importantes conceitos que seráo presentes em seus diversos escritos, em jornais, artigos e outras publicaçóes. No exílio, por exemplo, escreveu respeitáveis obras para as mulheres operárias e para animar o debate político-partidário. Já na Rússia, Krupskaya se envolveu mais com as massas e deixou em segun- 


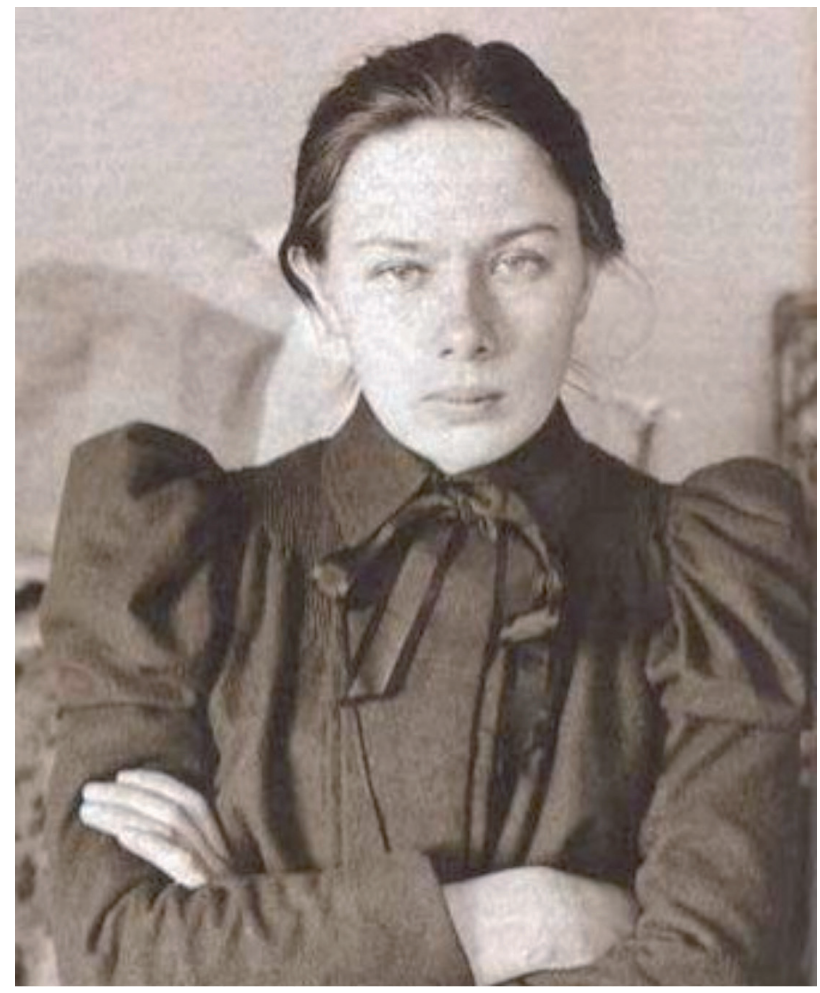

Foto de Nadezhda Konstantinovna Krupskaya na juventude.

Domínio público. Acervo dos autores.

do plano o Comitê Central do Partido, dedicando seu trabalho a instrução dos operários.

Após a vitória bolchevique em 1917, integrou o Comissariado do Povo para a Educação, ocasião em que colabora com Anatoli Lunacharski para definir as bases de um novo sistema educacional, com a finalidade de encerrar o analfabetismo (que era tratado como herança da monarquia). Krupskaya foi convidada a compor o quadro dirigente do comissariado, mas os altos cargos não lhe interessavam. Liderou a Seção Pedagógica da Comissão Científica Estatal, sendo responsável pela criação dos currículos e programas escolares. Ao longo de sua vida fez diversas publicaçóes em jornais, revistas entre outros, e essas publicaçóes foram selecionadas e reu- 
nidas no livro $A$ construção da pedagogia socialista, no qual é evidenciado o propósito de uma educação soviética.

Até agora, toda atenção foi dada à guerra, cada vez mais e mais atenção será direcionada às questôes da cultura e a organizaçáo da escola do trabalho será a tarefa principal. A escola atrairá para si novas forças e se tornará, por sua vez, 'uma ferramenta de transformação da sociedade moderna.. (KRUPSKAYA, 2017, p. 41)

Durante o novo governo socialista, creches, jardins de infância e locais para educaçáo de adultos foram criados, sendo assegurada a continuidade do ensino básico ao superior, com estabelecimentos públicos e gratuitos. A proposta essencial do socialismo tenta sempre ser colocada em prática. Uma das primeiras medidas a ser tomada na organizaçáo da nova nação socialista em relação a educação seria a erradicação do analfabetismo. Porém, Nadezhda acreditava que o povo não deveria se contentar apenas com a alfabetização, esta última deveria vir acompanhada dos elementos científicos de base para que houvesse uma conscientização da vida.

A proposta de educação que foi implantada na Uniâo das Repúblicas Socialistas Soviéticas (URSS) era para se adequar a realidade desta nação, à realidade socialista. Ainda mais que, para os seus principais artífices, seria imprescindível destruir o antigo modelo de escola burguesa e criar um que atendesse às necessidades do novo sistema socialista que estava sendo construído, com a unificação do sistema de ensino e a gestão centralizada, erradicando o analfabetismo e criando estabelecimentos públicos abertos para toda a população.

Em um Estado burguês - seja monarquia ou república -, a escola é instrumento de subjugação espiritual das grandes massas populares. $\mathrm{O}$ objetivo da escola, em tal Estado, não está atrelado aos interesses dos alunos, a não ser aos da classe dominante, quer dizer, a burguesia, e os interesses de uns e da outra divergem amiúde de modo assaz substancial. Por sua parte, o objetivo da escola condiciona toda a sua organização, todo seu modo de vida escolar, todo o conteúdo da instrução e a educação escolar. Se partirmos dos interesses da burguesia, o objeti- 
vo da escola variará segundo a camada da população à qual se destina. Destina-se às crianças da classe dominante, tem por objetivo preparar indivíduos capazes de desfrutar a vida e de governar. (KRUPSKAYA, 2017, p. 49)

Uma das críticas da autora é que antes a proposta educacional não só da Rússia, mas de toda Europa, era uma proposta burguesa, que separava, classificava e hierarquizava as pessoas, apenas dando acesso às camadas dominantes para que frequentassem a escola e tivessem acesso à educação. A educação deveria ser para todos e não só para as classes dominantes, pois sua grande crítica é que essa educação era somente para que as elites crescessem neste contexto educacional e, assim, somente as elites continuariam à frente da sociedade, nos cargos de governança, ou tomando partido das principais decisóes na vida da população.

A proposta da pedagogia socialista é que a educação atinja todas as pessoas de todas as camadas da sociedade, assim, construindo uma nação mais igualitária e participativa, sobretudo politicamente. Krupskaya reafirma essa proposta, apontando que por meio da educação o povo também conseguiria chegar aos cargos de governança. Ela acreditava que enquanto a escola estivesse nas mãos da burguesia, a escola do trabalho seria um instrumento dirigido contra os interesses da classe operária.

Outra questão apontada no trecho citado na página anterior é a intervenção do Estado na educação. Ela faz uma grande crítica defendendo que o estado não deveria intervir, pois a partir do momento em que isso acontece, o estado se apropria das principais questóes educacionais, transformando a educação em produto. Posto isso, o Estado teria a função de manter financeiramente as escolas públicas, mas não intervir nas questóes pedagógicas. A autora faz o mesmo apontamento a respeito da Igreja, relembrando que Estado e Igreja ao se apropriarem da educação, subjugam as massas.

Todas as ideias expostas por Krupskaya em seus manuscritos refletiram os ideais que foram propostos em um evento ainda durante o período anterior à revolução que ficaria conhecida como Congresso dos professores públicos ${ }^{5}$. Nesse congresso ficou decidido que haveria:

1) Educação geral, gratuita e obrigatória para todas as crianças, de ambos os sexos; 
2) Escola laica;

3) Organização democrática e não burocrática do trabalho escolar;

4) Garantia plena de liberdade de opiniáo e direito de associação aos professores;

5) Direito da população de receber educação em sua língua nativa, sem qualquer tipo de privilégio para qualquer língua.

Para o item 3, observamos um dos principais pontos da pedagogia socialista, a escola do trabalho, pois a escola teria também a função de um processo para se atingir a todos os trabalhadores, pois somente por meio da educação no trabalho é que se criaria a consciência de classes, fundamental para a construção de um mundo socialista.

Assim, a nova organização política refletiria nas questóes econômicas e sociais. Consequentemente, a escola também teria que se adaptar às mudanças, especialmente na questão da escola do trabalho, reorganizando a vida das pessoas, como podemos observar em seu escrito: "O desenvolvimento econômico requer insistentemente a transformação da escola de ensino em escola do trabalho, mas essa conversão não é viável sem uma reestruturação de toda organização da atividade da educação pública." (KRUPSKAYA, 2017, p. 38)

A educação será focada em uma educação pública e democrática (no sentido de atingir os proletários), pois deve abranger toda população, de ambos os sexos. Mas principalmente, que alcance todas as camadas da sociedade, desde as elites, aos camponeses das áreas rurais e os filhos de operários nas fábricas, todas as pessoas devem ter este acesso, ampliando o ensino. Seu método de trabalho propóe:

- Crítica coletiva do ver e do ouvir (todos devem trabalhar em prol da igualdade e da coletividade);

- Alcançar os objetivos através da união de forças;

- Divisão do trabalho de acordo com as forças e as possibilidades;

- Educação masculina e feminina.

A respeito da escola do trabalho os socialistas acreditam que esse modelo deva ocorrer desde a infância, porém, que não haja um abuso deste trabalho infantil (algo comum à época do czarismo russo), ofere- 
cendo condições para que a criança seja inserida no mundo real, pois se acreditava que somente através do trabalho as crianças (também) ganhariam uma consciência do que acontecia no mundo, da sua realidade, assim, a escola, com a sua função educativa, deveria também educar para o mundo do trabalho. Este trabalho deveria ser também produtivo, em sua forma de abordagem correta: coletiva. As crianças devem fazer escolhas daquilo que elas estão aptas a trabalhar ou não. As decisóes devem ser tomadas de maneira coletiva, assim como o trabalho que elas deverão executar.

Em sua proposta de educação, Krupskaya evidenciou a importância das fases de desenvolvimento infantil, enaltecendo os aspectos da formação psicológica em detrimento do bem coletivo. Ela fez uma divisão entre as crianças menores, a escola de primeiro grau, o ensino tecnicista, até chegar à vida adulta. Para ela, a escola de primeiro grau tem a função de despertar a curiosidade nos alunos, através de Teoria e Ciências, desenvolver o hábito de viver, estudar e trabalhar coletivamente.

Outro apontamento de seus escritos é nunca abandonar a teoria em função da prática. Assim percebemos a importância da parte teórica como guia para toda ação, por isso a escola do trabalho seria táo importante.

Também observamos a questão da auto-organização: como a proposta socialista é de coletividade, vemos formas de ação conjunta, como autodisciplina e a vontade coletiva. A escola deveria ser um modelo da sociedade sem classes.

Nós podemos dizer com toda certeza que a nova geração precisará de hábitos de organização em maior medida do que nós. E nós devemos, em relação a isso, apresentar-se para ajudá-la. Claro, a própria vida vai ensinar a organização para a juventude, mas é necessário que também a escola faça tudo o que puder em relaçấo a isso. A questấo da organizaçáo de toda a vida escolar - organização as tarefas, do trabalho, do descanso das crianças - deve estar agora no centro das atençóes do pedagogo. (KRUPSKAYA, 2017, p. 118-119)

Um dos principais pressupostos apontados é que a escola tinha a função de ensinar quais eram os objetivos do partido comunista, inse- 
rindo os jovens nas questóes políticas, influenciando o seu protagonismo estudantil partidário, "ajudar os jovens a tornar-se comunistas reais." (KRUPSKAYA, 2017, p. 237)

Krupskaya aponta, assim como Lênin, a importância de se educar bons ativistas. Em seus escritos nunca deixa de expor as ideias propostas pelos principais socialistas, incluindo Marx e seus ideais, retomando o caráter internacionalista do socialismo ${ }^{6}$ (e consequentemente da educação socialista).

Aqui é importante, sem dúvida, não só que os adolescentes memorizem slogans, mas é importante que desde cedo eles comecem a sentir a camaradagem, uma ligação amigável com os trabalhadores de todo o mundo. Precisamos educar também emocionalmente nossos filhos todos os dias para que dessa forma eles possam crescer comunistas autênticos, para completar a tarefa iniciada por seus pais. (KRUPSKAYA, 2017, p. 236)

Sobre a herança intelectual de Karl Marx, também, ela faz um importante apontamento sobre os três pilares na educação: educação mental; educação física; educação tecnológica, relembrando o caráter inseparável deste tripé para o êxito da educação socialista.

Outro importante apontamento para a educação é que a transformação apenas seria possível com a instrução dos professores, que não tinham o preparo necessário para executar a missão socialista até então. $\mathrm{O}$ educador deveria passar por um processo de formação antes de iniciar seu trabalho em sala de aula, pois "O próprio professor tem que saber muito e ainda ser capaz de fazer. Estudar, estudar e estudar - eis o que é necessário ao magistério russo." (KRUPSKAYA, 2017, p. 40)

Escreve também um artigo elencando o que um professor deveria dominar para ser um bom educador soviético, que seria fundamentalmente: Conhecer a sua matéria; Dominar o fundamento dialético da ciência; Capacidade de transmitir seus conhecimentos aos outros (ensinar); Demonstrar (dar exemplos); Ajudar o estudante a assimilar (memorizar); Ensinar a aplicar (os conhecimentos adquiridos); Dominar uma pedagogia (especificidades da criança e sua faixa etária). 
Pensando nas questóes propostas dentro do socialismo, Nadezhda faz uma crítica ao material escolar produzido pelo partido, apontando uma necessidade de revisão e inclusão de alguns itens, por exemplo, que deveria ser alterado o conceito de "ensino profissional" para "ensino politécnico", pois "o objetivo da escola não é preparar especialistas estreitos, mas pessoas que sejam capazes de executar todos os tipos de trabalho." (KRUPSKAYA, 2017, p. 62) Ela também acreditava que deveria ser feita uma retificação no que diz respeito a idade do trabalho assalariado: proibido para menores de 16 anos, que seriam crianças em idade escolar.

Contudo, fica evidente em seus escritos o seu conflito em propor uma escola de formação integral, com as propostas do partido que visavam a educação politécnica, essencialmente. Por exemplo: sua proposta é que este ensino técnico começasse aos 17 anos. O partido impõe que seu início seja aos 15 anos, antecipando a idade ideal proposta por Kruspkaya. Para demonstrar como funcionava o ensino técnico e profissional, Nadezhda fez diversas comparaçóes com os países que possuem o processo de proletarizaçáo em seu seio, como os Estados Unidos, a Inglaterra, França e Alemanha.

Com as mudanças políticas e econômicas na Rússia, Krupskaya ção, características da industrialização. "A reconstrução de toda economia nacional, desperta nas massas, inclusive nas crianças, o interesse pela técnica, o que cria condiçôes favoráveis para o ensino politécnico, aprofundando o interesse e fornecendo com ele uma base científica." (KRUPSKAYA, 2017, p. 150)

O politecnismo teria a função de abranger as diferentes áreas da vida e do conhecimento humano, postulando todas as áreas e disciplinas, como as tecnologias naturais, materiais, históricas, geográficas, econômicas e sociais, entre outras, sempre valorizando o universo do trabalho. Sua crítica é que esta forma de ensino serviria para o seu modelo de educação integral do trabalho, algo que não se fazia eficiente (ou útil) ao universo capitalista.

Além do ensino politécnico, a autora faz um levantamento do ensino por disciplinas, falando que este ensino não valoriza a formação integral dos jovens soviéticos, realizando uma nova proposta: ao invés do ensino 
por disciplinas, caberia ser trabalhado o ensino por Complexos. Este ensino por complexos eliminaria a fragmentação proposta pelas disciplinas (em História, Matemática, Ciências, Geografia etc.), propondo uma abordagem única, através de um eixo temático. As áreas seriam então estudadas de maneira conjunta, através de três grandes áreas: ciências exatas, ciências humanas e ciências biológicas. Nessas grandes áreas é que o educador deveria inserir seu trabalho, e náo nas disciplinas fragmentadas. Assim observamos um lugar e caráter da complexidade nos níveis de ensino, com:

- Distribuição temporal das tarefas;

- Diferentes métodos;

- Exigências metodológicas;

- Necessidade de interação do professor com a proposta.

O esforço para se compuser um quadro educacional que atinja os ideais socialistas são notórios. Mudanças no paradigma vigente educacional, de uma educação burguesa, com intervenção estatal e religiosa, para uma educação pública e gratuita são inovadoras à época. Ao exemplo de Kruspkaya, conseguimos observar também o quanto a escola estava preocupada com a inserção do povo em todas as esferas, econômicas, sociais e políticas, quando constrói a escola do trabalho e o ensino politécnico, ou quando propóe uma educação partidária desde cedo.

\section{Notas}

1 Em russo, Народный комиссариат просвещения, Наркомпрос, ou simplesmete Narkompros. Base para algumas das informaçóes utilizadas neste artigo.

2 Proletkult é a abreviatura da expressão proletarskaya kultura (cultura proletária). Foi um movimento cultural que surgiu na Rússia em 1917. Entre seus criadores estâo Alexander Bogdanov, Anatoli Lunacharsky e Mikhail Gerasimov.

3 Conferir: GRAMSCI, Antonio. Cadernos do cárcere, 6 vols. Ediçấo de Carlos Nelson Coutinho, com a colaboração de Luiz Sérgio Henriques e Marco Aurélio Nogueira. Rio de Janeiro, Civilização Brasileira, 1999-2002.

4 Conferir: GRAMSCI, Antonio. Os intelectuais e a organizaçấo da cultura. Rio de Janeiro: Civilização Brasileira, 1968.

5 Trata-se do Primeiro Congresso de Toda a Rússia para a Educaçáo pública, realizado em 1913 em São Petersburgo.

6 Sempre retomando em seus escritos o famoso slogan: "Proletários do mundo, uni-vos". 


\section{Consideraçóes finais}

Fundada por Lênin, Trotsky e outros bolcheviques, em 1919, a Internacional Comunista - pelo seu significado político e importância histórica da Revolução Russa -, se constituiu como a principal força dirigente dos partidos comunistas de todo o mundo nos primórdios do século XX que se intitulavam Seção da Internacional Comunista.

No Brasil, o Partido Comunista do Brasil (PCB) manifestou o seu interesse pela adesão na Internacional desde sua fundação, sendo admitido no IV Congresso, ocorrido em 1922, como Partido Simpatizante e, pouco depois, como Membro Pleno, no V Congresso, em 1924. A Internacional se manteve como o principal instrumento dirigente dos partidos de inspiração bolcheviques, pelo menos, até o início da Segunda Guerra Mundial, quando foram progressivamente encerradas suas atividades, até sua dissolução em 1943.

Contudo, ao retornarmos para os anos 1920 e 1930, veremos que muitos dos debates e antagonismos de propostas e concepçóes foram sendo superados no país dos sovietes e na Internacional. E os meios para que isso ocorresse inclui a vitória da ortodoxia soviética simbolizada na figura de Josef Stalin, que subjugou as demais vertentes políticas e filosóficas e estabelecendo o ideal do socialismo real soviético.

Antigas figuras de opiniōes diversas, como Krupskaya, Lunacharsky, Máximo Gorki e Anton Makarenko, foram obrigadas a se adaptarem à proposta política que alcançou o poder após a morte de Lênin em 1924, contribuindo para que o debate educacional no interior da Internacional Comunista não escapasse do modelo padrão e do "ideal” instituído pela visão stalinista do que seria o melhor para a defesa da Uniáo das Repúblicas Socialistas Soviéticas (URSS), desta forma, desconsiderando e combatendo a premissa trotskista de que a revolução socialista náo pode completarse apenas dentro dos limites nacionais.

Uma das causas essenciais da crise da sociedade burguesa resulta do fato das forças produtivas que esta criou tenderem a transcender os limites do Estado Nacional. Trotsky refuta a tese stalinista do socialismo num só país, defendendo que a revolução socialista começa no plano nacional, desenvolve-se mais à escala internacional e se completa à escala mundial. Assim, para Leon Trotsky, a revolução socialista torna-se permanente num 
sentido novo e amplo do termo, ou seja: sua conclusão só se verifica com a vitória definitiva da nova sociedade em todo o planeta. (TROTSKY, 2007)

No campo da política, da educação e da cultura - não descartando a possibilidade de outros nomes serem lembrados -, com suas páginas de intervenção revolucionária, Leon Trotsky, Nadezhda Krupskaya e Antônio Gramsci puderam inspirar um sem número de reflexôes ao longo dos anos, transcendendo o período histórico em que predominou a influência política da Internacional Comunista e chegando aos dias atuais, ainda mais que, em determinados escritos, práticas e postulados organizativos e revolucionários apresentassem críticas ao ideal stalinista em ascensão em diferentes partes do mundo, com isso, se transformado em referências teóricas para outros agrupamentos de inspiraçáo marxiana e intelectuais de esquerda que não compartilhavam do mesmo espectro burocrático e avesso a internacionalização dos ideais socialistas que se apossou do Estado soviético a partir de 1924.

\section{Referências}

BITTAR, Marisa. FERREIRA Jr., Amarílio. A educação na Rússia de Lênin. In Revista HISTEDBR On-line. 2011(41e), p. 377-396.

BROUÉ, Pierre. História da Internacional Comunista (1919-1943): a ascensão e a queda. Tomo I. Tradução de Fernando Ferrone. São Paulo: Sundermann, 2007.

FILONOV, G. N. Anton Makarenko. Tradução de Ester Buffa. Apresentação da edição brasileira, seleção de textos e organização de Carlos Bauer. Recife: Fundação Joaquim Nabuco: Ed. Massangana, 2010.

GRAMSCI, Antonio. Cadernos do cárcere, 6 vols. Edição de Carlos Nelson Coutinho, com a colaboração de Luiz Sérgio Henriques e Marco Aurélio Nogueira. Rio de Janeiro, Civilização Brasileira, 1999-2002.

GRAMSCI, Antonio. Os intelectuais e a organização da cultura.

Rio de Janeiro, Civilizaçáo Brasileira, 1968.

KRUPSKAYA, Nadezhda K. A construção da pedagogia socialista. Tradução: Natalya Pavlova e Luiz Carlos Freitas. Organização: Luiz Carlos Freitas e Roseli Salete Caldart. São Paulo: Expressão Popular, 2017. 
LODI, Samantha. Nadezhda Krupskaia: uma estrela vermelha. Uberlândia, MG: Navegando publicaçóes, 2018.

LEHER, Roberto. A pedagogia socialista nos processos revolucionários, organizaçôes politicas e movimentos sociais. In: CALDART, Roseli S. BÔAS, Rafael L. Villas (org.). Pedagogia socialista: legados da revolução de 1917 e desafios atuais. São Paulo: Expressão Popular, 2017.

MANACORDA, Mario A. História da educação: da antiguidade aos nossos dias. Tradução de Gaetano Lo Monaco. 9a ed., São Paulo: Cortez, 2001.

PONCE, Aníbal. Educação e luta de classes. São Paulo. Cortez, 17o edição, 2000.

TROTSKY, Leon. A revolução permanente. São Paulo: Expressão popular, 2007.

Recebido em 2I out. 2019 / Aprovado em I9 dez. 2019

\section{Para referenciar este texto:}

DINIZ, C.; BAUER, C.; DELCORSO, I. A educação na Internacional Comunista. EccoS - Revista Científica, São Paulo, n. 51, eI5894, out./dez. 2019. Disponível em: https://doi.org/I0.5585/EccoS.n5I.I5894. 